\title{
Endocrine fibroblast growth factors 15/19 and 21: from feast to famine
}

\author{
Matthew J. Potthoff, ${ }^{1,2}$ Steven A. Kliewer, ${ }^{1,3,4,5}$ and David J. Mangelsdorf ${ }^{1,2,4}$ \\ ${ }^{1}$ Department of Pharmacology, ${ }^{2}$ Howard Hughes Medical Institute, ${ }^{3}$ Department of Molecular Biology, University of Texas \\ Southwestern Medical Center, Dallas, Texas 75390, USA
}

We review the physiology and pharmacology of two atypical fibroblast growth factors (FGFs)-FGF15/19 and FGF21-that can function as hormones. Both FGF15/19 and FGF21 act on multiple tissues to coordinate carbohydrate and lipid metabolism in response to nutritional status. Whereas FGF15/19 is secreted from the small intestine in response to feeding and has insulin-like actions, FGF21 is secreted from the liver in response to extended fasting and has glucagon-like effects. FGF21 also acts in an autocrine fashion in several tissues, including adipose. The pharmacological actions of FGF15/19 and FGF21 make them attractive drug candidates for treating metabolic disease.

The discovery of hormones such as insulin and glucagon that regulate metabolism has a long and storied history. The field of endocrinology continues to be invigorated by the discovery of new metabolic hormones. Among the relatively recent additions are three fibroblast growth factors (FGFs), termed FGF15/19, FGF21, and FGF23. (FGF15 and FGF19 are the mouse and human orthologs, respectively, which we refer to as FGF15/19 unless specifically referring to one species or the other.) In contrast to most FGFs, which act in an autocrine or paracrine fashion, the three "endocrine FGFs" can be released into the bloodstream to act throughout the body. While the fundamental role that FGF23 plays in regulating phosphate metabolism has been known for more than a decade (White et al. 2000; Shimada et al. 2001), the discovery of FGF15/19 and FGF21 and their wide-ranging effects on carbohydrate and lipid metabolism has been more recent. This review focuses on FGF15/19 and FGF21.

Most FGF family members mediate their effects by binding to FGF receptors (FGFRs) on the cell surface (Beenken and Mohammadi 2009). FGFRs are receptor tyrosine kinases encoded by four genes (FGFR1-4), with alternate splicing of FGFR1-3 yielding two isoforms ("b" and " $\mathrm{c}$ ") that differ in their extracellular domains and ligand-binding profiles. Typically, FGFs require an addi-

\footnotetext{
[Keywords: FGF15; FGF19; FGF21; bile acids; obesity; diabetes]

${ }^{4}$ These authors contributed equally to this work.

${ }^{5}$ Corresponding author.

E-mail steven.kliewer@utsouthwestern.edu.

Article published online ahead of print. Article and publication date are online at http://www.genesdev.org/cgi/doi/10.1101/gad.184788.111.
}

tional interaction with heparan sulfate glycosaminoglycans in the extracellular matrix to activate their receptors. FGF binding to the FGFR/heparan sulfate complex causes receptor dimerization and autophosphorylation and the subsequent phosphorylation and activation of downstream substrates, including FGFR substrate $2 \alpha$, and MAP kinases such as ERK1 and ERK2 (Beenken and Mohammadi 2009).

Unlike conventional FGFs, the endocrine FGFs interact only weakly with heparan sulfate. As a consequence, they are able to diffuse away from their cells of origin and enter circulation (Goetz et al. 2007). To compensate for their inability to interact with heparan sulfate, the endocrine FGFs require members of the Klotho family of proteins for high-affinity receptor binding (Kurosu and Kuro 2009). There are three, related Klotho proteins: $\alpha$-Klotho, $\beta$-Klotho, and lactase-like. All three are single-pass transmembrane proteins that interact with FGFRs to enable selective binding of the three endocrine FGFs. $\alpha$-Klotho serves as the coreceptor for FGF23, and $\beta$-Klotho serves as the coreceptor for FGF15/19 and FGF21 (Kurosu et al. 2006, 2007; Urakawa et al. 2006; Ogawa et al. 2007; Wu et al. 2007; Kharitonenkov et al. 2008). FGF15/19 can also signal through lactase-like/FGFR complexes (Fon Tacer et al. 2010). While the FGFRs have very broad tissue distributions, expression of the Klotho proteins is more restricted (Fon Tacer et al. 2010). Thus, the sites of action for the endocrine FGFs are largely dictated by the presence or absence of the Klotho proteins.

\section{FGF15/19}

\section{Discovery and role in regulating bile acid homeostasis}

FGF19 was originally identified in a screen for novel FGFs in the fetal brain (Nishimura et al. 1999). While most FGFs are highly conserved between rodents and humans, sharing $>90 \%$ amino acid identity, FGF19 shares only $\sim 50 \%$ amino acid identity with its rodent ortholog, FGF15 (McWhirter et al. 1997). However, the Fgf15 and FGF19 genes are syntenic (Katoh 2003) and have similar tissue expression profiles (e.g., small intestine and fetal brain) (Nishimura et al. 1999; Xie et al. 1999; Gimeno et al. 2002; Inagaki et al. 2005; Krejci et al. 2007; Fon Tacer et al. 2010), and their protein products elicit similar effects on gene expression and metabolic parameters in mice (Inagaki et al. 2005; Potthoff et al. 2011). During mouse embryo- 
genesis, Fgf15 has a complex and dynamic pattern of expression in the CNS (McWhirter et al. 1997; Gimeno et al. 2002, 2003; Ishibashi and McMahon 2002). This includes prominent expression in secondary organizers of the brain, which induce and maintain the regional characteristics of the surrounding neuroepithelium. Studies done with FGF15 knockout (KO) embryos show that FGF15 suppresses proliferation and promotes differentiation of neural precursors (Borello et al. 2008; Fischer et al. 2011). Fgf15 is not detected in the adult CNS (Fon Tacer et al. 2010).

A primary function of FGF15/19 in the adult is to regulate bile acid homeostasis. Bile acids are amphipathic molecules that are released post-prandially from the gallbladder into the small intestine, where they play an essential role in the solubilization of dietary lipids (Russell 2003). After traversing the intestine, $\sim 95 \%$ of bile acids are reabsorbed in the ileum and returned to the liver and gallbladder via the portal vein. Because of their intrinsic toxicity, intracellular levels of bile acids must be tightly regulated, which is accomplished by the transcriptional regulation of proteins involved in bile acid biosynthesis, transport, and metabolism. Chief among the transcriptional regulators of bile acid homeostasis is the farnesoid $\mathrm{X}$ receptor (FXR), a member of the nuclear receptor family of ligand-activated transcription factors that is activated by the bile acids cholic acid and chenodeoxycholic acid (Kalaany and Mangelsdorf 2006). Among the genes regulated by FXR in the liver is cholesterol $7 \alpha$-hydroxylase (CYP7A1), which encodes the enzyme that catalyzes the first and rate-limiting step in the classical bile acid biosynthetic pathway (Russell and Setchell 1992; Chiang 1998). FXR potently represses $C Y P 7 A 1$ and thus bile acid synthesis through a two-pronged mechanism (Fig. 1). First, FXR induces hepatic expression of small heterodimer partner (SHP), an orphan nuclear receptor that binds to the CYP7A1 promoter and represses its transcription (Goodwin et al. 2000; Lu et al. 2000). Unlike most nuclear receptors, SHP lacks a DNA-binding domain and binds indirectly to the CYP7A1 promoter through interactions with two other orphan nuclear receptors: liver receptor homolog-1 (LRH-1) and hepatocyte nuclear factor $4 \alpha$ (HNF4 $\alpha$ ) (Goodwin et al. 2000; Lu et al. 2000; De Fabiani et al. 2001). The importance of the FXR-SHP pathway in bile acid homeostasis has been demonstrated in FXR-KO and SHP-KO mice, both of which have increased Cyp7a1 expression and corresponding increase in bile acid pool size (Kerr et al. 2002; Wang et al. 2002; Kok et al. 2003).

FGF15/19 is part of a second, interrelated mechanism through which bile acids feed back to repress their own synthesis (Fig. 1). It has been known for more than two decades that intestinal administration of bile acids suppresses $C Y P 7 A 1$, suggesting that the intestine produces a secreted factor that acts on the liver to repress bile acid synthesis (Pandak et al. 1991; Nagano et al. 2004). FGF19 was first implicated as this factor when it was shown that FXR agonists induced FGF19 in cultured human hepatocytes and, further, that FGF19 repressed CYP7A1 expression in both isolated hepatocytes and mice (Holt et al. 2003). Subsequent studies showed that FXR-mediated re-

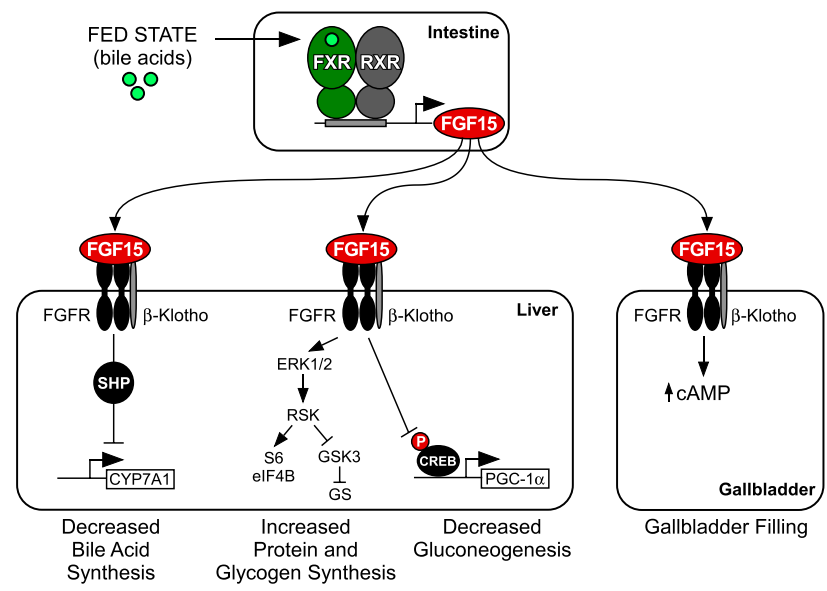

Figure 1. Endocrine actions of FGF15. FGF15 expression is induced in the small intestine by bile acids acting on the FXR/RXR heterodimer. Secreted FGF15 acts on FGFR/ $\beta$-Klotho receptor complexes in the liver to repress CYP7A1 and bile acid synthesis through a mechanism that requires SHP, to induce protein synthesis through activation of the ERK1/2-RSK pathway that activates translation factors S6 and eIF4B, to stimulate glycogen synthase (GS) activity and glycogen synthesis through inactivation of glycogen synthase kinase 3 (GSK3), and to repress gluconeogenesis by blocking the phosphorylation and activation of CREB, a transcription factor that induces peroxisome proliferator-activated receptor $\gamma$ coactivator $1-\alpha(P G C-1 \alpha)$ and other gluconeogenic genes. FGF15 also acts on the gallbladder to increase cAMP levels, which promotes filling of the gallbladder with bile.

pression of Cyp7a1 was lost in FGF15-KO mice, demonstrating the physiological importance of this pathway (Inagaki et al. 2005). While the initial studies suggested that FGF15/19 might be part of an autocrine pathway in liver, more recent studies in mice showed that FGF15/19 is not normally made in hepatocytes, but is instead expressed in ileal enterocytes, where it is induced by bile acids acting on FXR (Inagaki et al. 2005). Consistent with these findings, FXR-mediated repression of Cyp7a1 requires the presence of FXR in the intestine but not the liver (Kim et al. 2007a). In humans, circulating FGF19 concentrations increase in response to oral administration of bile acids and decrease in response to treatment with bile acid sequestrants, demonstrating that the regulation of FGF15/ 19 is conserved (Lundasen et al. 2006; Brufau et al. 2010). Thus, FGF15/19 signals from the intestine to the liver to regulate bile acid homeostasis.

FGF15/19 represses CYP7A1 in the liver by binding to the FGFR4/ $\beta$-Klotho receptor complex. As was observed in FGF15-KO mice, FGFR4-KO and $\beta$-Klotho-KO mice have increased Cyp7a1 expression and bile acid synthesis, and administration of exogenous FGF15/19 fails to repress Cyp7a1 in these animals (Yu et al. 2000; Inagaki et al. 2005; Ito et al. 2005; Tomiyama et al. 2010). Conversely, transgenic overexpression of a constitutively active FGFR4 in either wild-type or FGFR4-KO mice decreased Cyp7a1 expression and bile acid pool size (Yu et al. 2005). Importantly, FGF15/19-mediated repression of Cyp7a1 is lost in SHP-KO mice (Inagaki et al. 2005), demonstrating that the 
FGF15/19 and SHP pathways converge. The mechanistic basis for this cooperativity is not yet known. One possibility is that FGF15/19 increases the stability of SHP by preventing its ubiquitination (Miao et al. 2009). However, since increased basal SHP expression in the liver has only relatively modest effects on Cyp7a1 expression compared with FGF19 administration (Boulias et al. 2005; Inagaki et al. 2005; Potthoff et al. 2011), this is unlikely to account for the full effect of FGF19 on CYP7A1.

Recent studies indicate that the FGF19-CYP7A1 pathway has medical relevance in humans. Circulating FGF19 concentrations are high in patients with extrahepatic cholestasis, a condition in which bile flow from the liver is impeded (Schaap et al. 2009). Interestingly, FGF19 is expressed in the liver under these disease conditions, suggesting the existence of an adaptive response to reign in bile acid production. Conversely, low serum FGF19 concentrations were found in patients with idiopathic bile acid malabsorption (Walters et al. 2009), a disease associated with excess bile acid production and chronic diarrhea. Based on these findings, it was proposed that low FGF19 serum levels, not defective ileal reuptake of bile acids, are the basis for this disease (Walters et al. 2009). Another study found a single-nucleotide polymorphism in $\beta$-Klotho, which regulated $\beta$-Klotho protein stability and was associated with colonic transit in diarrheapredominant irritable bowel syndrome (Wong et al. 2011). In a mouse model of bile acid malabsorption, FGF15 administration suppressed Cyp7a1 and normalized the bile acid pool (Jung et al. 2007). These findings raise the intriguing possibility that FGF15/19 or FXR agonists may have utility in the treatment of diseases associated with excess bile acids.

In addition to its effects on bile acid synthesis, FGF15/ 19 also regulates gallbladder filling (Fig. 1). FGF15-KO mice have a virtually empty gallbladder even in the fasted state, when the gallbladder is normally full (Choi et al. 2006). Likewise, FGFR4-KO and $\beta$-Klotho-KO mice have small gallbladders (Yu et al. 2000; Ito et al. 2005). Injection of recombinant FGF19 into FGF15-KO mice causes a rapid filling of the gallbladder without stimulating bile flow. This effect is mediated in part via relaxation of the gallbladder smooth muscle (Choi et al. 2006). We conclude that FGF15/19 plays an overarching role in regulating bile acid homeostasis, including the post-prandial refilling of the gallbladder. Interestingly, in humans but not mice, FGF19 is abundantly expressed in the gallbladder, where it is secreted into the bile, not the blood (Zweers et al. 2011). The physiological consequences of this exocrine secretion of FGF19 remain to be determined.

\section{FGF15/19 in energy homeostasis}

A role for FGF19 in controlling energy homeostasis was first discovered using FGF19 transgenic mice. Mice with constitutively elevated levels of FGF19 have lower body weights due to reduced fat content, despite having elevated food intake (Tomlinson et al. 2002). In this study, reduced adiposity and increased food intake were explained by elevated energy expenditure resulting from increased brown adipose tissue (BAT) mass and enhanced hepatic lipid oxidation. FGF19 transgenic mice were also protected from diet-induced obesity and had lower serum glucose, insulin, cholesterol, and triglyceride levels. Administration of recombinant FGF19 to mice fed a high-fat diet recapitulated most of these metabolic effects (Fu et al. 2004). To date, the molecular basis of these changes has not been elucidated, and this remains an active area of research.

Consistent with the effects of FGF15/19 on metabolism, FGFR4-KO mice show characteristics of metabolic syndrome, including dyslipidemia, hypercholesterolemia, increased adiposity, and glucose intolerance (Huang et al. 2007). Paradoxically, however, obese FGFR4-KO mice have reduced hepatic triglyceride and cholesterol levels due to increased hepatic fatty acid oxidation and hepatic triglyceride secretion (Huang et al. 2007). Interestingly, reexpression of a constitutively active form of FGFR4 in the liver of FGFR4-KO mice decreased plasma lipid and cholesterol levels but failed to improve the glucose tolerance and insulin sensitivity that is seen with FGF19 treatment (Huang et al. 2007). In addition, administering FGF19 to FGFR4-KO mice on a high-fat diet improved glucose homeostasis (Wu et al. 2011). Thus, FGF19 requires FGFR4 in the liver to improve dyslipidema and hypercholesterolemia but not hyperglycemia and insulin resistance.

How does FGF15/19 impact carbohydrate metabolism? While FGF19 acts preferentially through FGFR4 (Xie et al. 1999; Kurosu et al. 2007), it also binds and activates FGFR1c, which is abundantly expressed in white adipose tissue (WAT) but not in hepatocytes (Kurosu et al. 2007). Administration of FGF19 to isolated adipocytes increases FGF signaling and glucose uptake in a $\beta$-Klotho-dependent manner, and FGF19 administration induces ERK1/2 signaling in murine WAT (Kurosu et al. 2007; Wu et al. 2009). In addition to WAT, FGF19 may act on other tissues. For example, intracerebroventricular injection of FGF19 increased the metabolic rate, suggesting that FGF19 can act directly on the CNS (Fu et al. 2004). Thus, the pharmacological effects of FGF19 on metabolism may involve signaling through multiple FGFRs in multiple tissues.

Two recent studies demonstrated physiological roles for FGF15/19 in regulating glucose homeostasis. Kir et al. (2011) showed that FGF15-KO mice are glucose-intolerant and store $50 \%$ less hepatic glycogen than wild-type mice. Consistent with this finding, pharmacological administration of FGF15/19 stimulated hepatic glycogen synthesis (Fig. 1). FGF19 increased hepatic glycogen synthase activity by inducing the phosphorylation and inactivation of glycogen synthase kinase $3 \alpha$ and $3 \beta$ (Kir et al. 2011). Administration of FGF19 to mice devoid of insulin restored hepatic glycogen concentrations to normal, demonstrating the insulin-independent effects of this endocrine pathway. These findings may explain why IRS1/ IRS2-KO mice, which lack insulin signaling in the liver, are still able to store hepatic glycogen after a meal (Dong et al. 2006). In addition to glycogen synthesis, FGF19 also activated components of the protein translation machinery and increased hepatic protein synthesis in vivo (Kir et al. 
2011). Mechanistically, FGF19 uses a RAS-ERK-p90RSK pathway to induce phosphorylation of ribosomal protein S6 and eukaryotic initiation factors eIF4B and eIF4E.

In addition to stimulating glycogen synthesis and protein synthesis in the liver, FGF15/19 also represses gluconeogenesis (Fig. 1; Potthoff et al. 2011). Overexpression of FGF15 in lean mice suppressed hepatic gluconeogenesis without affecting insulin sensitivity. The physiological importance of FGF15 was demonstrated using FGF15$\mathrm{KO}$ and FGFR4-KO mice, which were hyperglycemic and had elevated gluconeogenesis in the fed state (Potthoff et al. 2011). FGF15/19 represses gluconeogenesis by inhibiting the activity of the transcription factor CREB, a key regulator of peroxisome proliferator-activated receptor $\gamma$ coactivator-1 $\alpha(P g c-1 \alpha)$ and other gluconeogenic genes.

The overlap in the effects of FGF15/19 and insulin on hepatic metabolism is striking: Both stimulate hepatic glycogen and protein synthesis and repress gluconeogenesis. However, there are important differences. First, unlike insulin, FGF15/19 does not stimulate lipogenesis, which is a key advantage in considering the FGF19 pathway as an anti-diabetic therapy. Second, whereas insulin acts through the insulin receptor-PI3K-Akt pathway, FGF15/ 19 mediates its effects through the FGFR/ $\beta-$ Klotho-ERKRSK pathway. Finally, there are important temporal differences. Insulin is released within minutes of a meal, and in rodent experiments, serum insulin concentrations and downstream hepatic Akt phosphorylation peak $\sim 15 \mathrm{~min}$ after a high-carbohydrate/high-fat meal. In contrast, Fgf15 mRNA levels in ileum and downstream ERK1/2 phosphorylation in the liver peak $\sim 1 \mathrm{~h}$ after feeding (Potthoff et al. 2011). Likewise, in humans, FGF19 serum levels peak $\sim 2 \mathrm{~h}$ after a meal (Lundasen et al. 2006), and, accordingly, circulating FGF19 levels in humans negatively correlate with fasting glucose levels and metabolic syndrome (Stejskal et al. 2008; Reiche et al. 2010; Mraz et al. 2011). Thus, FGF15/19 acts after insulin in the transition from the fed to the fasted state. Taken together, these studies establish a post-prandial hormonal program in which insulin and FGF15/19 coordinately govern nutrient metabolism.

FGF15/19 in cancer

Although the studies discussed above point to a novel therapeutic use for FGF19 in treating diabetes, an important caveat is that chronic administration of FGF19 stimulates proliferation. FGF19 transgenic mice develop hepatocellular carcinomas (HCCs) and liver dysplasia by 10-12 mo of age (Nicholes et al. 2002), and an FGF19neutralizing antibody inhibited tumor formation in this model (Desnoyers et al. 2008). Recently, FGF19 was shown to be amplified and overexpressed in human HCCs. In mouse xenograft studies, a neutralizing antibody to FGF19 blocked the growth of a human HCC cell line harboring the amplified FGF19 gene (Sawey et al. 2011).

As with the effects of FGF15/19 on metabolism, there is controversy as to whether its proliferative effects are mediated through FGFR4. Although one study showed that FGFR4 is required for FGF19-stimulated growth (Wu et al. 2010b), deletion of FGFR4 accelerates HCC progression in a carcinogen-initiated mouse model of tumor- igenesis (Huang et al. 2009). A possible explanation for these seemingly contradictory findings is that the FGFR4FGF19 pathway has both pro- and anti-carcinogenic actions. For example, while on the one hand FGF19 induces $\beta$-catenin and cell proliferation (Nicholes et al. 2002; Desnoyers et al. 2008; Pai et al. 2008), it also suppresses the synthesis of bile acids, which are tumor promoters. Several other mouse KO models that increase bile acid synthesis, including the FXR-KO and SHP-KO mice, also spontaneously develop HCCs (Kim et al. 2007b; Yang et al. 2007; Y Zhang et al. 2008). Thus, FGF19 may alternately suppress or enhance tumorigenesis through different mechanisms. There has been keen pharmacological interest in developing novel FGF19 mimetics that eliminate the growth-promoting effects while preserving the potent metabolic effects of FGF19. To this end, it was recently shown that replacement of two short regions of FGF19 eliminated its proliferative effects without affecting its glucose-lowering actions in ob/ob mice (Wu et al. 2010a).

\section{FGF21}

The study of FGF21 exploded with the discovery of its potent insulin-sensitizing actions in rodents (Kharitonenkov et al. 2005). However, despite this plethora of work, much of the biology of FGF21 and its mechanism of action remain controversial and incompletely understood. Part of the problem in developing a coherent understanding of FGF21 has come from trying to compare its systemic pharmacological effects in obese animals with its tissue-specific effects that occur under more physiological conditions. In this next section, we attempt to provide some clarity to this complex picture by considering the pharmacological and physiological actions of FGF21 within the context of the different experimental conditions in which they have been observed.

\section{Discovery and pharmacological actions}

Fgf21 was isolated from a mouse embryo cDNA library in a screen for new FGF family members and was shown to be abundantly expressed in the adult mouse liver (Nishimura et al. 2000). A role for FGF21 in regulating metabolism was first reported by Kharitonenkov et al. (2005), who showed that FGF21 induced glucose transporter-1 and promoted glucose uptake in murine 3T3-L1 and human primary adipocytes. In this and subsequent studies done in genetic and diet-induced models of obesity, it was shown that FGF21 administration decreased hepatic triglycerides, decreased plasma triglycerides and glucose levels, and caused weight loss by increasing energy expenditure and reducing fat mass without decreasing food intake (Kharitonenkov et al. 2005; Coskun et al. 2008; $\mathrm{Xu}$ et al. 2009a). In similar studies performed with diabetic rhesus monkeys, FGF21 decreased plasma glucose, insulin, and triglyceride concentrations; lowered LDL cholesterol and increased HDL cholesterol levels; and caused modest but significant weight loss (Kharitonenkov et al. 2007). Overall, FGF21 was shown to have remarkable beneficial effects on several metabolic parameters in obese rodents and primates. 
Consistent with its effects on glucose and lipid metabolism, a prominent feature of the pharmacological studies with FGF21 is its profound effect on insulin sensitivity. When administered to insulin-resistant rodents, a single injection of FGF21 decreases blood glucose concentrations and improves glucose tolerance and insulin sensitivity in both leptin-deficient ob/ob mice and diet-induced obese mice (Xu et al. 2009b). In diet-induced obese mice, these changes are accompanied by increased wholebody glucose turnover without a decrease in hepatic glucose production. Treatment of diet-induced obese mice with FGF21 for longer periods (3-6 wk) reverses hepatic steatosis, decreases hepatic glucose production, and increases insulin-stimulated glucose uptake in the heart, adipose tissue, and skeletal muscle (Xu et al. 2009a). Likewise, administration of FGF21 to ob/ob mice for $8 \mathrm{~d}$ improves hepatic insulin sensitivity and also increases liver glycogen content (Berglund et al. 2009). However, there was no effect of FGF21 on insulin-stimulated glucose uptake in peripheral tissues in ob/ob mice. While the basis for this difference is not clear, there is agreement that FGF21 improves insulin sensitivity at least in part through effects on hepatic metabolism.

On which tissues does FGF21 act directly to regulate metabolism? FGF21 functions through receptors composed of $\beta$-Klotho and either FGFR1c, FGFR2c, or FGFR3c (Ogawa et al. 2007; Kharitonenkov et al. 2008; Suzuki et al. 2008). While these FGFRs are ubiquitously expressed, $\beta$-Klotho is enriched in several metabolically active tissues, including the liver, WAT, and BAT (Ito et al. 2000; Fon Tacer et al. 2010). Consistent with this profile, FGF21 stimulates ERK1/2 phosphorylation and modulates gene expression in each of these tissues (Kurosu et al. 2007; Fisher et al. 2010). While relatively little is known about how FGF21 regulates transcription, it reduces levels of the lipogenic transcription factor sterol regulatory elementbinding protein-1 in the liver (Badman et al. 2009b; Xu et al. 2009a) and induces expression of the metabolic coactivator protein PGC-1 $\alpha$ in the liver and WAT (Badman et al. 2009b; Potthoff et al. 2009; Chau et al. 2010; Fisher et al. 2011). $\beta$-Klotho is also expressed in both the endocrine and exocrine pancreas (Johnson et al. 2009; J Repa, pers. comm.). In rat pancreatic islets, FGF21 treatment stimulates ERK1/2 and Akt signaling and increases insulin mRNA and protein levels (Wente et al. 2006). Accordingly, FGF21 treatment increases islet number and insulin staining in $\mathrm{db} / \mathrm{db}$ mice, suggesting that preservation of $\beta$-cell function contributes to the beneficial glycemic actions of FGF21 (Wente et al. 2006). Finally, $\beta$-Klotho is expressed in the hypothalamus (Coskun et al. 2008), although its precise localization in this tissue has yet to be reported. FGF21 appears able to cross the blood-brain barrier (Hsuchou et al. 2007), and direct intracerebroventricular infusion of FGF21 into the brains of diet-induced obese rats increases food intake and energy expenditure and increases insulin sensitivity due to increased insulin-induced suppression of both hepatic glucose production and gluconeogenic gene expression (Sarruf et al. 2010). In a study in which FGF21 was administered for 2 wk by injection, FGF21 increased expression of the orexigenic hormone neuropeptide $\mathrm{Y}$
(NPY) and decreased expression of the anorexigenic hormone pro-opiomelanocortin in the hypothalamus (Coskun et al. 2008). Thus, the pharmacological effects of FGF21 are likely to be a consequence of it acting both centrally and peripherally. While one study reported that FGF21 can function in the absence of $\beta$-Klotho to induce an immediate early transcription factor (Tomiyama et al. 2010), no additional parameters were measured in these experiments, and it remains to be determined whether FGF21 has $\beta$-Klotho-independent actions.

\section{Physiological actions of FGF21}

In contrast to the insulin-sensitizing, pharmacological actions of FGF21 that are observed in obese animals, the physiological actions of FGF21 occur in lean animals. In addition, whereas the pharmacological effects include the systemic action of FGF21 in multiple organ systems and tissues (e.g., liver, pancreas, adipose, and CNS), the physiological actions are likely to occur at lower hormone concentrations and in a more restricted set of tissues. Important clues as to the physiology of FGF21 have come initially from studying its regulation. FGF21 expression is induced in various tissues in response to fasting, feeding, and cold. Summaries of the role of FGF21 in these responses follow.

FGF21 in fasting and starvation In 2007, three groups showed that FGF2 1 is strongly induced in the mouse liver by fasting $\geq 12 \mathrm{~h}$ (Badman et al. 2007; Inagaki et al. 2007; Lundasen et al. 2007). Optimal induction of FGF21 by fasting requires the glucagon receptor (Berglund et al. 2010), which is consistent with FGF21 acting subsequent to glucagon in the temporal cascade of hormones that regulate the fasting response. There is also evidence that FGF21 feeds back to suppress glucagon concentrations (Kharitonenkov et al. 2005, 2007; Berglund et al. 2009). Fasting-mediated induction of FGF21 requires the peroxisome proliferator-activated receptor $\alpha(\operatorname{PPAR} \alpha)$, a nuclear receptor activated by fatty acids and the fibrate class of hypolipidemic drugs (Badman et al. 2007; Inagaki et al. 2007; Lundasen et al. 2007). PPAR $\alpha$ binds directly to the Fgf21 gene promoter to induce its transcription (Inagaki et al. 2007). PPAR $\alpha$ plays a crucial role in the adaptive starvation response: PPAR $\alpha$-KO mice are unable to adequately catabolize fatty acids in the liver and, as a consequence, become steatotic, hypoketonemic, hypoglycemic, and hypothermic during fasts lasting $\geq 24 \mathrm{~h}$ (Kersten et al. 1999; Leone et al. 1999; Hashimoto et al. 2000). This hypoketonemia and hepatic steatosis can be partially reversed by administration of exogenous FGF21 to the PPAR $\alpha$-KO mice (Inagaki et al. 2007). FGF21 is also strongly induced in the mouse liver by a high-fat, lowcarbohydrate "ketogenic" diet (Badman et al. 2007) and by suckling in mouse neonates (Hondares et al. 2010), conditions that mimic starvation in forcing the body to burn fatty acids rather than carbohydrates. FGF21 has effects in lean mice on metabolism, growth, and the phenomenon of torpor that are all consistent with an important role for FGF21 in coordinating the adaptive starvation 
response. These effects are summarized in Figure 2 and are discussed below.

Metabolism: In the fed state, FGF21 transgenic mice have increased hepatic tricarboxylic acid cycle flux, gluconeogenesis, fatty acid oxidation, and ketogenesis (Potthoff et al. 2009). FGF21 induces hepatic expression of the transcriptional coactivator protein PGC- $1 \alpha$, which stimulates transcription of genes involved in each of these metabolic pathways. However, the importance of PGC-1 $\alpha$ induction for FGF21 action remains in question (Potthoff et al. 2009; Fisher et al. 2011). While the metabolic actions of FGF21 are similar to those of glucagon, FGF21 does not increase glycogenolysis (Potthoff et al. 2009), which is consistent with it being induced 12-24 h into a fast, when glycogen reserves are already depleted. Acute knockdown of FGF21 in the livers of mice fed a ketogenic diet causes hepatic steatosis (Badman et al. 2007), demonstrating that FGF21 is required for the efficient catabolism of fatty acids. Like PPAR $\alpha$-KO mice, FGF21-KO mice become hypoglycemic during a 24-h fast, although the effect is more modest (Potthoff et al. 2009). These data reveal an important role for FGF21 in regulating glucose production and fatty acid catabolism during starvation.

Growth: During starvation, circulating growth hormone $(\mathrm{GH})$ concentrations increase to stimulate lipolysis. However, the anabolic actions of $\mathrm{GH}$, including the induction

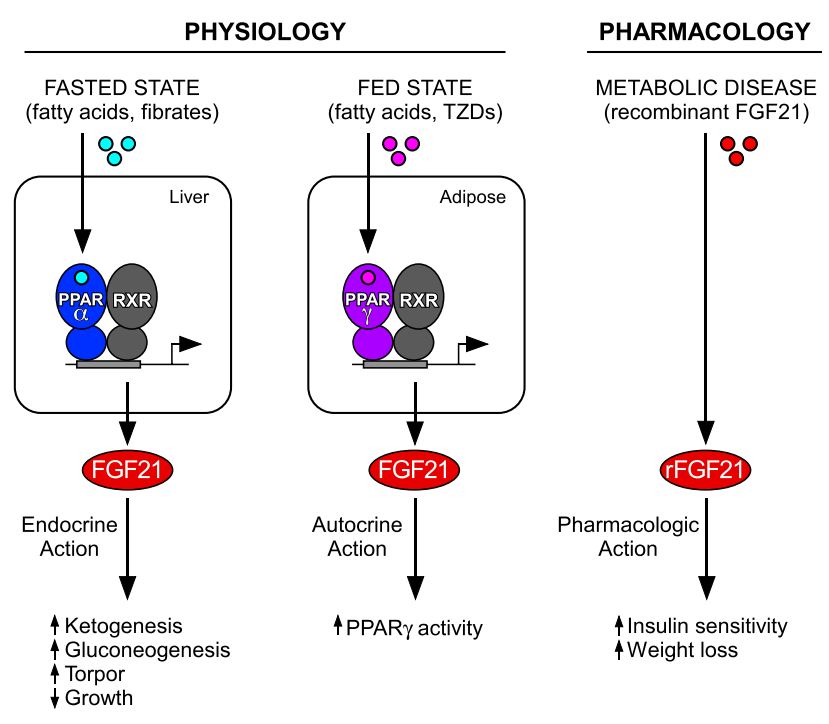

Figure 2. Endocrine, autocrine, and pharmacological actions of FGF21. (Left panel) In response to fasting or fibrate drugs, FGF21 expression is induced in the liver by the PPAR $\alpha / R X R$ heterodimer. Secreted FGF21 acts as an endocrine hormone to induce ketogenesis, gluconeogenesis, and torpor and to inhibit somatic growth. (Middle panel) In response to feeding or thiazolidinedione drugs (TZDs), FGF21 expression is induced by the PPAR $\gamma /$ RXR heterodimer in WAT, where FGF21 acts through an autocrine mechanism to stimulate PPAR $\gamma$ activity. (Right panel) Pharmacological administration of recombinant FGF21 (rFGF21) affects multiple tissues and has beneficial effects in metabolic disease. of its downstream effector, insulin-like growth factor 1 (IGF-1), are lost in starving animals (Thissen et al. 1994). This phenomenon of dissociating the catabolic from the anabolic effects of GH is referred to as "growth hormone resistance." A remarkable phenotype of FGF21 transgenic mice is their diminutive size: FGF21 transgenic mice weigh substantially less than wild-type mice, while retaining their appropriate body proportions (Inagaki et al. 2008). Growth retardation is not due to a decrease in GH concentrations. Rather, basal GH concentrations are modestly increased. Notably, circulating IGF-1 concentrations are reduced in FGF21 transgenic mice, as are hepatic levels of the active, phosphorylated form of the transcription factor STAT5, a major regulator of IGF-1 transcription (Inagaki et al. 2008). These studies reveal a role for FGF21 in inducing growth hormone resistance as part of the adaptive starvation response.

Torpor: Torpor is a starvation-induced phenomenon in which body temperature and physical activity are reduced to conserve energy. Depending on the species, torpor can reduce energy utilization by as much as $90 \%$ (Geiser 2004). A possible link between FGF21 and torpor was first suggested by the induction of pancreatic lipases in the livers of FGF21 transgenic mice, a phenomenon previously observed in torpid mice (Zhang et al. 2006). This extrapancreatic induction of lipases may provide a means for the continuous hydrolysis of fatty acids under conditions of reduced body temperature (Squire et al. 2003). Under fed conditions, FGF21 transgenic mice do not have reductions in body temperature or activity. However, during a 24-h fast, FGF21 transgenic mice exhibit an $\sim 10^{\circ} \mathrm{C}$ drop in body temperature, accompanied by a marked decrease in physical activity (Inagaki et al. 2007). Importantly, FGF21 is not sufficient to cause torpor. Rather, its overexpression sensitizes lean mice to starvation-induced torpor. This effect is not a function of reduced adiposity, since wild-type and FGF21 transgenic mice have comparable amounts of adipose tissue (Inagaki et al. 2008). Studies with FGF21-KO mice showed that FGF21 is not required for hypothermia or reduced physical activity during a 24-h fast (Oishi et al. 2010). However, ketogenic diet-induced hypothermia was reduced in FGF21-KO mice, suggesting that FGF21 may be important in controlling torpor under conditions of longer-term starvation.

How might FGF21 affect torpor? One possibility is via regulation of hypothalamic NPY, which regulates fastinginduced torpor. FGF21 administration increases NPY mRNA levels in the hypothalamus (Coskun et al. 2008). Similarly, treatment of mice with a fibrate PPAR agonist induces hypothermia, accompanied by increased NPY expression in the hypothalamus, and an NPY-Y1 receptor antagonist prevents this fibrate-mediated hypothermia (Chikahisa et al. 2008). However, neither $\operatorname{PPAR} \alpha$ nor FGF21 is essential for fasting-mediated induction of NPY (Oishi et al. 2010). These data suggest that there is redundancy in the regulation of NPY and that the effects of FGF21 on body temperature and physical activity are likely to depend on the metabolic status of the animals. 
FGF21 in cold adaptation Morphologic alterations in BAT from FGF21 transgenic mice first suggested that FGF21 may regulate thermogenesis (Kharitonenkov et al. 2005). Two groups subsequently showed that FGF21 is induced by cold in BAT (Chartoumpekis et al. 2011; Hondares et al. 2011), although it is unclear whether BAT-derived FGF21 acts hormonally or just locally in BAT itself. Injection of FGF21 into mice stimulated the expression of thermogenic genes such as uncoupling protein-1 and deiodinase-2 in BAT and uncoupling protein-1 in WAT (Coskun et al. 2008; Hondares et al. 2010). Consistent with this activation of BAT and "browning" of WAT, FGF21 administration causes weight loss in obese rodents and monkeys, with more striking weight loss in rodents, which have more BAT (Kharitonenkov et al. 2005, 2007; Coskun et al. 2008; Xu et al. 2009a). An interesting conundrum is how FGF21 contributes to both decreases (i.e., torpor) and increases in body temperature. As suggested above, the response elicited by FGF21 is likely a function of both the physiological context (e.g., cold or starvation) and the tissues that are exposed to FGF21 under these conditions. Interestingly, catecholamines show the same dichotomy in that they are required for both torpor and thermogenesis (Swoap and Weinshenker 2008).

FGF21 in feeding In a surprising twist, FGF21 is induced in the liver by high-carbohydrate diets (Ma et al. 2006; Uebanso et al. 2011) and in WAT by fastingrefeeding regimens (Oishi et al. 2011; Dutchak et al. 2012). These responses in the liver and WAT are likely mediated by carbohydrate response element-binding protein and PPAR $\gamma$, respectively (Ma et al. 2006; Muise et al. 2008; Wang et al. 2008; Iizuka et al. 2009). Regarding $\operatorname{PPAR} \gamma$, we recently showed that the full insulinsensitizing effects of the thiazolidinedione drug (TZD) rosiglitazone, a potent PPAR $\gamma$ agonist, require FGF2 1 (Dutchak et al. 2012). Importantly, diet-induced obese FGF21-KO mice are refractory to both the beneficial, insulin-sensitizing effects of TZDs and TZD side effects such as weight gain and fluid retention. FGF21 stimulates $\operatorname{PPAR} \gamma$ at least in part by preventing its post-translational sumoylation and inactivation. These results reveal FGF21 to be part of a feed-forward regulatory pathway that contributes to the fed-state response in WAT (Fig. 2). Notably, unlike the fasting response that elicits FGF21 release from the liver into circulation, feeding and pharmacological induction of FGF21 in WAT do not cause a corresponding increase in circulating levels of FGF21 protein (Dutchak et al. 2012). Thus, FGF21 acts in an autocrine or paracrine fashion in WAT, much like canonical FGFs. In this regard, basal expression of FGF21 is high in the exocrine pancreas under nonfasted conditions when circulating FGF21 is low (Fon Tacer et al. 2010). Thus, the release of FGF21 into the blood by tissues may be the exception rather than the rule.

We suggest two possibilities as to why a hormone that elicits diverse aspects of the starvation response is also induced in WAT by feeding. First, FGF21 may regulate the efficient capture of nutrients when they become available following an extended fast. In support of this idea, FGF21 is very strongly induced in WAT under fasting-refeeding conditions (Oishi et al. 2011). Thus, the actions of FGF21 in WAT may represent an extension of its role in the adaptive starvation response. A second possibility is that FGF21 regulates pathways that are important in both the fed and fasted states. A prominent example of this is triglyceride synthesis. In the fed state, glucose and fatty acids are converted to triglyceride in the liver and WAT, with most triglyceride ultimately stored in WAT. However, triglyceride synthesis also occurs during fasting, when only a small fraction of the free fatty acids released by lipolysis are immediately oxidized. Most free fatty acids are re-esterified to triglyceride by various tissues, including WAT and the liver (Reshef et al. 2003). This socalled "triglyceride/fatty acid cycle" may serve as a mechanism for controlling the delivery of fatty acids and glycerol to the liver and other tissues during starvation. A role for FGF21 in this pathway may explain why FGF21-KO mice have elevated plasma triglyceride and free fatty acid concentrations during fasting (Hotta et al. 2009; Potthoff et al. 2009). Moreover, a role for FGF21 in the triglyceride/fatty acid cycle may also help explain why FGF21 has alternately been reported to stimulate or repress lipolysis (Inagaki et al. 2007; Arner et al. 2008; Li et al. 2009). In experiments in lean, fed FGF21 transgenic mice and in lean, fed wild-type mice injected with recombinant FGF21, circulating free fatty acid concentrations were increased (Inagaki et al. 2007). These studies further showed that FGF21 treatment increased expression of hormone-sensitive lipase and adipose triglyceride lipase in murine adipose and induced glycerol release from differentiated 3T3-L1 adipocytes, a surrogate measure of lipolysis. While there is agreement that FGF21 increases lipase expression in adipose (Inagaki et al. 2007; Coskun et al. 2008), other groups have observed that FGF21 treatment decreases free fatty acid release from 3T3-L1 adipocytes and primary cultures of human adipocytes (Arner et al. 2008; Li et al. 2009), and FGF21 administration lowers circulating free fatty acids in obese mice $(\mathrm{Xu}$ et al. 2009a). The pro- and anti-lipolytic effects of FGF21 are reminiscent of those of PPAR $\gamma$ agonists (Oakes et al. 2001; Nagashima et al. 2005; Festuccia et al. 2006; Kershaw et al. 2007). We conclude that the effects of FGF21 on adipose are complex and likely depend on the precise physiological or pathophysiological context.

An adverse consequence of the effect of FGF21 on adipocytes occurs in bone, where pharmacological levels of FGF21 decrease bone mass (Wei et al. 2012). Conversely, FGF21-KO mice have increased bone mass. FGF21 causes bone loss in part by enhancing the differentiation of bone marrow mesenchymal stem cells into adipocytes instead of osteoblasts (Wei et al. 2012). Bone loss is a potential clinical concern as FGF21 is developed as a drug for treating metabolic disease.

\section{FGF21: mice vs. humans}

How is FGF21 regulated in humans? As in mice, circulating FGF21 levels are induced by fibrates and other PPAR $\alpha$ 
agonists in humans (Galman et al. 2008; Christodoulides et al. 2009; Mraz et al. 2011). Circulating FGF21 concentrations are also increased in rheumatoid arthritis patients fasted for $7 \mathrm{~d}$ (Galman et al. 2008) and in obese individuals fed a very low-calorie diet for $3 \mathrm{wk}$ (Mraz et al. 2011). While these data suggest similarities in the way that FGF21 is regulated across species, the magnitude of FGF21 induction by PPAR $\alpha$ agonists and fasting is modest in humans compared with mice. Notably, circulating FGF21 levels are not increased in humans by either shorter-term fasts or ketogenic diets (Galman et al. 2008; Christodoulides et al. 2009; Dushay et al. 2010) or in subjects with anorexia nervosa (Dostalova et al. 2008; Fazeli et al. 2010), suggesting that there may be important differences in the regulation and function of FGF21 between rodents and humans.

It also remains to be determined whether the function of FGF21 as a fed-state hormone is conserved between mice and humans. While some groups have detected FGF21 mRNA in human WAT (X Zhang et al. 2008; Mraz et al. 2009), others have not (Dushay et al. 2010). Interestingly, circulating FGF21 concentrations are increased in human subjects who either are overweight or have type 2 diabetes, impaired glucose tolerance, or nonalcoholic fatty liver disease (Chen et al. 2008; Chavez et al. 2009; Mraz et al. 2009; Cuevas-Ramos et al. 2010; Dushay et al. 2010; Li et al. 2010, 2011; Matuszek et al. 2010; Yilmaz et al. 2010). It seems likely that this circulating FGF21 is derived from the liver, perhaps due to the induction of FGF21 by elevated hepatic lipid and carbohydrate levels. While the human findings appear to be at odds with the insulin-sensitizing actions of FGF21 in rodents and monkeys, hepatic FGF21 mRNA levels and plasma FGF21 concentrations are similarly increased in diet-induced and genetically obese mice (Muise et al. 2008; X Zhang et al. 2008; Badman et al. 2009a; Fisher et al. 2010). Importantly, these mice still respond to pharmacological doses of FGF21 with improved insulin sensitivity. One possibility is that obesity and insulin resistance cause "FGF21 resistance" in rodents and humans. While a study from one group supports this hypothesis (Fisher et al. 2010), another study does not (Hale et al. 2011). The basis and consequences of increased FGF21 in metabolic disease remain to be determined.

\section{Summary}

Insulin and glucagon are the prototypical fed- and fastedstate hormones. In this context, FGF15/19 and FGF21 can be considered "late-acting" fed- and fasted-state hormones, respectively, acting on the heels of insulin and glucagon to regulate metabolism in response to nutritional status (Fig. 3). While FGF15/19 and FGF21 have effects that overlap with those of insulin and glucagon, they also have their own distinct actions. For example, FGF21 sensitizes mice to torpor and suppresses growth, whereas glucagon does not have these effects. A surprising twist to the paradigm of FGF21 serving as a starvation hormone is that it also functions as a fed-state signal in WAT and the liver. Moreover, while both FGF15/19 and

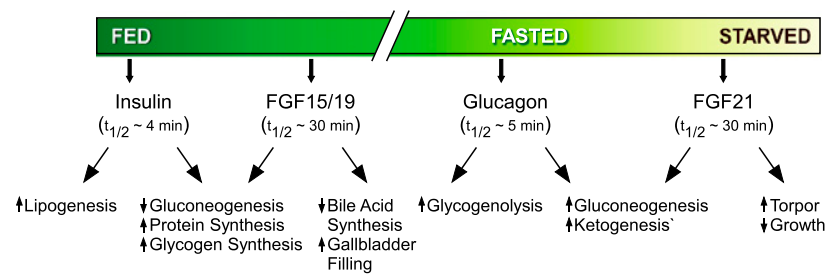

Figure 3. FGF15/19 and FGF21 function in a temporal cascade of hormones to regulate responses to nutritional stress. The temporal relationship among insulin, FGF15/19, glucagon, and FGF21 is shown along with hormone half-lives and biological actions.

FGF21 circulate as hormones, there is emerging evidence that they can also function as autocrine or exocrine factors. While reconciling all of these findings into a simple model is difficult, we conclude that FGF15/19 and FGF21 play important roles in coordinating energy homeostasis under a variety of nutritional conditions.

Both FGF15/19 and FGF21 have remarkable pharmacological effects on carbohydrate and lipid metabolism, particularly in the context of obese animals. Their similar effects on weight loss and insulin action suggest that they may act through some of the same tissues and pathways, but this remains to be determined. The pharmacological actions of FGF15/19 and FGF21 make them attractive as future drugs for treating metabolic disease. Indeed, FGF21 is already in clinical trials. However, given their pleiotropic effects, additional studies will be required to address the safety of their long-term use. Obvious concerns include the effects of FGF19 and FGF21 on hepatocyte proliferation and bone mass, respectively. For FGF19, there is already evidence that it may be possible to engineer safer versions of this hormone for use in humans (Wu et al. 2010a). In any case, based on their profound pharmacological and physiological effects on metabolism, the endocrine FGFs appear poised to have their own long and storied history.

\section{Acknowledgments}

We thank members of the Mangelsdorf/Kliewer laboratory for discussion. This work was supported by National Institutes of Health grants 5R01DK067158 and RL1GM084436 (to D.J.M. and S.A.K.), the Robert A. Welch Foundation (I-1275 to D.J.M. and I-1558 to S.A.K.), and the Howard Hughes Medical Institute (to M.J.P. and D.J.M.).

\section{References}

Arner P, Pettersson A, Mitchell PJ, Dunbar JD, Kharitonenkov A, Ryden M. 2008. FGF21 attenuates lipolysis in human adipocytes-a possible link to improved insulin sensitivity. FEBS Lett 582: 1725-1730.

Badman MK, Pissios P, Kennedy AR, Koukos G, Flier JS, Maratos-Flier E. 2007. Hepatic fibroblast growth factor 21 is regulated by PPAR $\alpha$ and is a key mediator of hepatic lipid metabolism in ketotic states. Cell Metab 5: 426-437.

Badman MK, Kennedy AR, Adams AC, Pissios P, Maratos-Flier E. 2009a. A very low carbohydrate ketogenic diet improves glucose tolerance in ob/ob mice independent of weight loss. 
Am I Physiol Endocrinol Metab 297: E1197-E1204. doi: 10.1152/ajpendo.00357.2009.

Badman MK, Koester A, Flier JS, Kharitonenkov A, MaratosFlier E. 2009b. Fibroblast growth factor 21-deficient mice demonstrate impaired adaptation to ketosis. Endocrinology 150: 4931-4940.

Beenken A, Mohammadi M. 2009. The FGF family: Biology, pathophysiology and therapy. Nat Rev Drug Discov 8: 235-253.

Berglund ED, Li CY, Bina HA, Lynes SE, Michael MD, Shanafelt $\mathrm{AB}$, Kharitonenkov A, Wasserman DH. 2009. Fibroblast growth factor 21 controls glycemia via regulation of hepatic glucose flux and insulin sensitivity. Endocrinology 150: 4084-4093.

Berglund ED, Kang L, Lee-Young RS, Hasenour CM, Lustig DG, Lynes SE, Donahue EP, Swift LL, Charron MJ, Wasserman DH. 2010. Glucagon and lipid interactions in the regulation of hepatic AMPK signaling and expression of PPAR $\alpha$ and FGF21 transcripts in vivo. Am I Physiol Endocrinol Metab 299: E607-E614. doi: 10.1152/ajpendo.00263.2010.

Borello U, Cobos I, Long JE, McWhirter JR, Murre C, Rubenstein JL. 2008. FGF15 promotes neurogenesis and opposes FGF8 function during neocortical development. Neural Dev 3: 17. doi: 10.1186/1749-8104-3-17.

Boulias K, Katrakili N, Bamberg K, Underhill P, Greenfield A, Talianidis I. 2005. Regulation of hepatic metabolic pathways by the orphan nuclear receptor SHP. EMBO J 24: 2624-2633.

Brufau G, Stellaard F, Prado K, Bloks VW, Jonkers E, Boverhof R, Kuipers F, Murphy EJ. 2010. Improved glycemic control with colesevelam treatment in patients with type 2 diabetes is not directly associated with changes in bile acid metabolism. Hepatology 52: 1455-1464.

Chartoumpekis DV, Habeos IG, Ziros PG, Psyrogiannis AI, Kyriazopoulou VE, Papavassiliou AG. 2011. Brown adipose tissue responds to cold and adrenergic stimulation by in duction of FGF21. Mol Med 17: 736-740.

Chau MD, Gao J, Yang Q, Wu Z, Gromada J. 2010. Fibroblast growth factor 21 regulates energy metabolism by activating the AMPK-SIRT1-PGC-1 $\alpha$ pathway. Proc Natl Acad Sci 107: 12553-12558.

Chavez AO, Molina-Carrion M, Abdul-Ghani MA, Folli F, Defronzo RA, Tripathy D. 2009. Circulating fibroblast growth factor-21 is elevated in impaired glucose tolerance and type 2 diabetes and correlates with muscle and hepatic insulin resistance. Diabetes Care 32: 1542-1546.

Chen WW, Li L, Yang GY, Li K, Qi XY, Zhu W, Tang Y, Liu H, Boden G. 2008. Circulating FGF-21 levels in normal subjects and in newly diagnose patients with Type 2 diabetes mellitus. Exp Clin Endocrinol Diabetes 116: 65-68.

Chiang JY. 1998. Regulation of bile acid synthesis. Front Biosci 3: d176-d193.

Chikahisa S, Tominaga K, Kawai T, Kitaoka K, Oishi K, Ishida N, Rokutan K, Sei H. 2008. Bezafibrate, a peroxisome proliferator-activated receptors agonist, decreases body temperature and enhances electroencephalogram delta-oscillation during sleep in mice. Endocrinology 149: 5262-5271.

Choi M, Moschetta A, Bookout AL, Peng L, Umetani M, Holmstrom SR, Suino-Powell K, Xu HE, Richardson JA, Gerard RD, et al. 2006. Identification of a hormonal basis for gallbladder filling. Nat Med 12: 1253-1255.

Christodoulides C, Dyson P, Sprecher D, Tsintzas K, Karpe F. 2009. Circulating fibroblast growth factor 21 is induced by peroxisome proliferator-activated receptor agonists but not ketosis in man. J Clin Endocrinol Metab 94: 3594-3601.

Coskun T, Bina HA, Schneider MA, Dunbar JD, Hu CC, Chen Y, Moller DE, Kharitonenkov A. 2008. Fibroblast growth factor 21 corrects obesity in mice. Endocrinology 149: 6018-6027.
Cuevas-Ramos D, Almeda-Valdes P, Gomez-Perez FJ, MezaArana CE, Cruz-Bautista I, Arellano-Campos O, NavarreteLopez M, Aguilar-Salinas CA. 2010. Daily physical activity, fasting glucose, uric acid, and body mass index are independent factors associated with serum fibroblast growth factor 21 levels. Eur J Endocrinol 163: 469-477.

De Fabiani E, Mitro N, Anzulovich AC, Pinelli A, Galli G, Crestani M. 2001. The negative effects of bile acids and tumor necrosis factor- $\alpha$ on the transcription of cholesterol $7 \alpha$-hydroxylase gene (CYP7A1) converge to hepatic nuclear factor-4: A novel mechanism of feedback regulation of bile acid synthesis mediated by nuclear receptors. I Biol Chem 276: 30708-30716.

Desnoyers LR, Pai R, Ferrando RE, Hotzel K, Le T, Ross J, Carano R, D'Souza A, Qing J, Mohtashemi I, et al. 2008. Targeting FGF19 inhibits tumor growth in colon cancer xenograft and FGF19 transgenic hepatocellular carcinoma models. Oncogene 27: 85-97.

Dong X, Park S, Lin X, Copps K, Yi X, White MF. 2006. Irs1 and Irs2 signaling is essential for hepatic glucose homeostasis and systemic growth. J Clin Invest 116: 101-114.

Dostalova I, Kavalkova P, Haluzikova D, Lacinova Z, Mraz M, Papezova H, Haluzik M. 2008. Plasma concentrations of fibroblast growth factors 19 and 21 in patients with anorexia nervosa. I Clin Endocrinol Metab 93: 3627-3632.

Dushay J, Chui PC, Gopalakrishnan GS, Varela-Rey M, Crawley M, Fisher FM, Badman MK, Martinez-Chantar ML, MaratosFlier E. 2010. Increased fibroblast growth factor 21 in obesity and nonalcoholic fatty liver disease. Gastroenterology 139: 456-463.

Dutchak PA, Katafuchi T, Bookout AL, Choi JH, Yu RT, Mangelsdorf DI, Kliewer SA. 2012. Fibroblast growth factor- 21 regulates PPAR- $\gamma$ activity and the antidiabetic actions of thiazolidinediones. Cell 148: 556-567.

Fazeli PK, Misra M, Goldstein M, Miller KK, Klibanski A. 2010. Fibroblast growth factor-21 may mediate growth hormone resistance in anorexia nervosa. J Clin Endocrinol Metab 95: 369-374.

Festuccia WT, Laplante M, Berthiaume M, Gelinas Y, Deshaies Y. 2006. PPAR $y$ agonism increases rat adipose tissue lipolysis, expression of glyceride lipases, and the response of lipolysis to hormonal control. Diabetologia 49: 2427-2436.

Fischer T, Faus-Kessler T, Welzl G, Simeone A, Wurst W, Prakash N. 2011. Fgf15-mediated control of neurogenic and proneural gene expression regulates dorsal midbrain neurogenesis. Dev Biol 350: 496-510.

Fisher FM, Chui PC, Antonellis PJ, Bina HA, Kharitonenkov A, Flier JS, Maratos-Flier E. 2010. Obesity is a fibroblast growth factor 21 (FGF21)-resistant state. Diabetes 59: 2781-2789.

Fisher FM, Estall JL, Adams AC, Antonellis PJ, Bina HA, Flier JS, Kharitonenkov A, Spiegelman BM, Maratos-Flier E. 2011. Integrated regulation of hepatic metabolism by fibroblast growth factor 21 (FGF21) in vivo. Endocrinology 152: 29963004.

Fon Tacer K, Bookout AL, Ding X, Kurosu H, John GB, Wang L, Goetz R, Mohammadi M, Kuro-o M, Mangelsdorf DJ, et al. 2010. Research resource: Comprehensive expression atlas of the fibroblast growth factor system in adult mouse. Mol Endocrinol 24: 2050-2064.

Fu L, John LM, Adams SH, Yu XX, Tomlinson E, Renz M, Williams PM, Soriano R, Corpuz R, Moffat B, et al. 2004. Fibroblast growth factor 19 increases metabolic rate and reverses dietary and leptin-deficient diabetes. Endocrinology 145: 2594-2603.

Galman C, Lundasen T, Kharitonenkov A, Bina HA, Eriksson M, Hafstrom I, Dahlin M, Amark P, Angelin B, Rudling M. 2008. 
The circulating metabolic regulator FGF21 is induced by prolonged fasting and PPAR $\alpha$ activation in man. Cell Metab 8: $169-174$.

Geiser F. 2004. Metabolic rate and body temperature reduction during hibernation and daily torpor. Annu Rev Physiol 66: 239-274.

Gimeno L, Hashemi R, Brulet P, Martinez S. 2002. Analysis of Fgf15 expression pattern in the mouse neural tube. Brain Res Bull 57: 297-299.

Gimeno L, Brulet P, Martinez S. 2003. Study of Fgf15 gene expression in developing mouse brain. Gene Expr Patterns 3: 473-481.

Goetz R, Beenken A, Ibrahimi OA, Kalinina J, Olsen SK, Eliseenkova AV, Xu C, Neubert TA, Zhang F, Linhardt RJ, et al. 2007. Molecular insights into the klotho-dependent, endocrine mode of action of fibroblast growth factor 19 subfamily members. Mol Cell Biol 27: 3417-3428.

Goodwin B, Jones SA, Price RR, Watson MA, McKee DD, Moore LB, Galardi C, Wilson JG, Lewis MC, Roth ME, et al. 2000. A regulatory cascade of the nuclear receptors FXR, SHP-1, and LRH-1 represses bile acid biosynthesis. Mol Cell 6: 517-526.

Hale C, Chen MM, Stanislaus S, Chinookoswong N, Hager T, Wang M, Veniant MM, Xu J. 2011. Lack of overt FGF21 resistance in two mouse models of obesity and insulin resistance. Endocrinology 153: 69-80.

Hashimoto T, Cook WS, Qi C, Yeldandi AV, Reddy JK, Rao MS. 2000. Defect in peroxisome proliferator-activated receptor $\alpha$-inducible fatty acid oxidation determines the severity of hepatic steatosis in response to fasting. I Biol Chem 275: $28918-28928$.

Holt JA, Luo G, Billin AN, Bisi J, McNeill YY, Kozarsky KF, Donahee M, Wang DY, Mansfield TA, Kliewer SA, et al. 2003. Definition of a novel growth factor-dependent signal cascade for the suppression of bile acid biosynthesis. Genes Dev 17: 1581-1591.

Hondares E, Rosell M, Gonzalez FJ, Giralt M, Iglesias R, Villarroya F. 2010. Hepatic FGF21 expression is induced at birth via PPAR $\alpha$ in response to milk intake and contributes to thermogenic activation of neonatal brown fat. Cell Metab 11: 206-212.

Hondares E, Iglesias R, Giralt A, Gonzalez FJ, Giralt M, Mampel T, Villarroya F. 2011. Thermogenic activation induces FGF21 expression and release in brown adipose tissue. J Biol Chem 286: $12983-12990$.

Hotta Y, Nakamura H, Konishi M, Murata Y, Takagi H, Matsumura S, Inoue K, Fushiki T, Itoh N. 2009. Fibroblast growth factor 21 regulates lipolysis in white adipose tissue but is not required for ketogenesis and triglyceride clearance in liver. Endocrinology 150: 4625-4633.

Hsuchou H, Pan W, Kastin AJ. 2007. The fasting polypeptide FGF21 can enter brain from blood. Peptides 28: 2382-2386.

Huang X, Yang C, Luo Y, Jin C, Wang F, McKeehan WL. 2007. FGFR4 prevents hyperlipidemia and insulin resistance but underlies high-fat diet induced fatty liver. Diabetes 56: 2501-2510.

Huang X, Yang C, Jin C, Luo Y, Wang F, McKeehan WL. 2009. Resident hepatocyte fibroblast growth factor receptor 4 limits hepatocarcinogenesis. Mol Carcinog 48: 553-562.

Iizuka K, Takeda J, Horikawa Y. 2009. Glucose induces FGF21 mRNA expression through ChREBP activation in rat hepatocytes. FEBS Lett 583: 2882-2886.

Inagaki $T$, Choi $M$, Moschetta $A$, Peng $L$, Cummins $C L$, McDonald JG, Luo G, Jones SA, Goodwin B, Richardson JA, et al. 2005. Fibroblast growth factor 15 functions as an enterohepatic signal to regulate bile acid homeostasis. Cell Metab 2: 217-225.
Inagaki T, Dutchak P, Zhao G, Ding X, Gautron L, Parameswara V, Li Y, Goetz R, Mohammadi M, Esser V, et al. 2007. Endocrine regulation of the fasting response by $\operatorname{PPAR} \alpha$ mediated induction of fibroblast growth factor 21. Cell Metab 5: 415-425.

Inagaki T, Lin VY, Goetz R, Mohammadi M, Mangelsdorf DJ, Kliewer SA. 2008. Inhibition of growth hormone signaling by the fasting-induced hormone FGF21. Cell Metab 8: 77-83.

Ishibashi M, McMahon AP. 2002. A Sonic Hedgehog-dependent signaling relay regulates growth of diencephalic and mesencephalic primordia in the early mouse embryo. Development 129: 4807-4819.

Ito S, Kinoshita S, Shiraishi N, Nakagawa S, Sekine S, Fujimori T, Nabeshima YI. 2000. Molecular cloning and expression analyses of mouse $\beta$ klotho, which encodes a novel Klotho family protein. Mech Dev 98: 115-119.

Ito S, Fujimori T, Furuya A, Satoh J, Nabeshima Y. 2005. Impaired negative feedback suppression of bile acid synthesis in mice lacking $\beta$ Klotho. J Clin Invest 115: 2202-2208.

Johnson CL, Weston JY, Chadi SA, Fazio EN, Huff MW, Kharitonenkov A, Koester A, Pin CL. 2009. Fibroblast growth factor 21 reduces the severity of cerulein-induced pancreatitis in mice. Gastroenterology 137: 1795-1804.

Jung D, Inagaki T, Gerard RD, Dawson PA, Kliewer SA, Mangelsdorf DI, Moschetta A. 2007. FXR agonists and FGF15 reduce fecal bile acid excretion in a mouse model of bile acid malabsorption. J Lipid Res 48: 2693-2700.

Kalaany NY, Mangelsdorf DJ. 2006. LXRS and FXR: The yin and yang of cholesterol and fat metabolism. Annu Rev Physiol 68: 159-191.

Katoh M. 2003. Evolutionary conservation of CCND1ORAOV1-FGF19-FGF4 locus from zebrafish to human. Int J Mol Med 12: 45-50.

Kerr TA, Saeki S, Schneider M, Schaefer K, Berdy S, Redder T, Shan B, Russell DW, Schwarz M. 2002. Loss of nuclear receptor SHP impairs but does not eliminate negative feedback regulation of bile acid synthesis. Dev Cell 2: 713720.

Kershaw EE, Schupp M, Guan HP, Gardner NP, Lazar MA, Flier JS. 2007. PPAR $\gamma$ regulates adipose triglyceride lipase in adipocytes in vitro and in vivo. Am J Physiol Endocrinol Metab 293: E1736-E1745. doi: 10.1152/ajpendo.00122.2007.

Kersten S, Seydoux J, Peters JM, Gonzalez FJ, Desvergne B, Wahli W. 1999. Peroxisome proliferator-activated receptor $\alpha$ mediates the adaptive response to fasting. J Clin Invest 103: 1489-1498.

Kharitonenkov A, Shiyanova TL, Koester A, Ford AM, Micanovic R, Galbreath EJ, Sandusky GE, Hammond LJ, Moyers IS, Owens RA, et al. 2005. FGF-21 as a novel metabolic regulator. I Clin Invest 115: 1627-1635.

Kharitonenkov A, Wroblewski VI, Koester A, Chen YF, Clutinger CK, Tigno XT, Hansen BC, Shanafelt AB, Etgen GJ. 2007. The metabolic state of diabetic monkeys is regulated by fibroblast growth factor-21. Endocrinology 148: 774-781.

Kharitonenkov A, Dunbar JD, Bina HA, Bright S, Moyers JS, Zhang C, Ding L, Micanovic R, Mehrbod SF, Knierman MD, et al. 2008. FGF-21/FGF-21 receptor interaction and activation is determined by $\beta$ Klotho. I Cell Physiol 215: $1-7$.

Kim I, Ahn SH, Inagaki T, Choi M, Ito S, Guo GL, Kliewer SA, Gonzalez FJ. 2007a. Differential regulation of bile acid homeostasis by the farnesoid $\mathrm{X}$ receptor in liver and intestine. J Lipid Res 48: 2664-2672.

Kim I, Morimura K, Shah Y, Yang Q, Ward JM, Gonzalez FJ. 2007b. Spontaneous hepatocarcinogenesis in farnesoid $\mathrm{X}$ receptor-null mice. Carcinogenesis 28: 940-946. 
Kir S, Beddow SA, Samuel VT, Miller P, Previs SF, Suino-Powell K, Xu HE, Shulman GI, Kliewer SA, Mangelsdorf DJ. 2011. FGF19 as a postprandial, insulin-independent activator of hepatic protein and glycogen synthesis. Science 331: 16211624.

Kok T, Hulzebos CV, Wolters $\mathrm{H}$, Havinga $\mathrm{R}$, Agellon LB, Stellaard F, Shan B, Schwarz M, Kuipers F. 2003. Enterohepatic circulation of bile salts in farnesoid $\mathrm{X}$ receptordeficient mice: Efficient intestinal bile salt absorption in the absence of ileal bile acid-binding protein. J Biol Chem 278: 41930-41937.

Krejci P, Krakow D, Mekikian PB, Wilcox WR. 2007. Fibroblast growth factors $1,2,17$, and 19 are the predominant FGF ligands expressed in human fetal growth plate cartilage. Pediatr Res 61: 267-272.

Kurosu H, Kuro OM. 2009. Endocrine fibroblast growth factors as regulators of metabolic homeostasis. Biofactors 35: 52-60.

Kurosu H, Ogawa Y, Miyoshi M, Yamamoto M, Nandi A, Rosenblatt KP, Baum MG, Schiavi S, Hu MC, Moe OW, et al. 2006. Regulation of fibroblast growth factor-23 signaling by klotho. J Biol Chem 281: 6120-6123.

Kurosu H, Choi M, Ogawa Y, Dickson AS, Goetz R, Eliseenkova AV, Mohammadi M, Rosenblatt KP, Kliewer SA, Kuro-o M. 2007. Tissue-specific expression of $\beta$ Klotho and fibroblast growth factor (FGF) receptor isoforms determines metabolic activity of FGF19 and FGF21. J Biol Chem 282: 2668726695.

Leone TC, Weinheimer CJ, Kelly DP. 1999. A critical role for the peroxisome proliferator-activated receptor $\alpha(\operatorname{PPAR} \alpha)$ in the cellular fasting response: The PPAR $\alpha$-null mouse as a model of fatty acid oxidation disorders. Proc Natl Acad Sci 96: 7473-7478.

Li X, Ge H, Weiszmann J, Hecht R, Li YS, Veniant MM, Xu J, Wu $\mathrm{X}$, Lindberg R, Li Y. 2009. Inhibition of lipolysis may contribute to the acute regulation of plasma FFA and glucose by FGF21 in ob/ob mice. FEBS Lett 583: 3230-3234.

Li H, Fang Q, Gao F, Fan J, Zhou J, Wang X, Zhang H, Pan X, Bao $\mathrm{Y}$, Xiang K, et al. 2010. Fibroblast growth factor 21 levels are increased in nonalcoholic fatty liver disease patients and are correlated with hepatic triglyceride. J Hepatol 53: 934-940.

Li X, Fan X, Ren F, Zhang Y, Shen C, Ren G, Sun J, Zhang N, Wang W, Ning G, et al. 2011. Serum FGF21 levels are increased in newly diagnosed type 2 diabetes with nonalcoholic fatty liver disease and associated with hsCRP levels independently. Diabetes Res Clin Pract 93: 10-16.

Lu TT, Makishima M, Repa JJ, Schoonjans K, Kerr TA, Auwerx J, Mangelsdorf DJ. 2000. Molecular basis for feedback regulation of bile acid synthesis by nuclear receptors. Mol Cell 6: 507-515.

Lundasen T, Galman C, Angelin B, Rudling M. 2006. Circulating intestinal fibroblast growth factor 19 has a pronounced diurnal variation and modulates hepatic bile acid synthesis in man. J Intern Med 260: 530-536.

Lundasen T, Hunt MC, Nilsson LM, Sanyal S, Angelin B, Alexson SE, Rudling M. 2007. PPAR $\alpha$ is a key regulator of hepatic FGF21. Biochem Biophys Res Commun 360: $437-$ 440.

Ma L, Robinson LN, Towle HC. 2006. ChREBP^Mlx is the principal mediator of glucose-induced gene expression in the liver. J Biol Chem 281: 28721-28730.

Matuszek B, Lenart-Lipinska M, Duma D, Solski J, Nowakowski A. 2010. Evaluation of concentrations of FGF-21-a new adipocytokine in type 2 diabetes. Endokrynol Pol 61: 50-54.

McWhirter JR, Goulding M, Weiner JA, Chun J, Murre C. 1997. A novel fibroblast growth factor gene expressed in the developing nervous system is a downstream target of the chimeric homeodomain oncoprotein E2A-Pbx1. Development 124: 3221-3232.

Miao J, Xiao Z, Kanamaluru D, Min G, Yau PM, Veenstra TD, Ellis E, Strom S, Suino-Powell K, Xu HE, et al. 2009. Bile acid signaling pathways increase stability of small heterodimer partner (SHP) by inhibiting ubiquitin-proteasomal degradation. Genes Dev 23: 986-996.

Mraz M, Bartlova M, Lacinova Z, Michalsky D, Kasalicky M, Haluzikova D, Matoulek M, Dostalova I, Humenanska V, Haluzik M. 2009. Serum concentrations and tissue expression of a novel endocrine regulator fibroblast growth factor21 in patients with type 2 diabetes and obesity. Clin Endocrinol (Oxf) 71: 369-375.

Mraz M, Lacinova Z, Kavalkova P, Haluzikova D, Trachta P, Drapalova J, Hanusova V, Haluzik M. 2011. Serum concentrations of fibroblast growth factor 19 in patients with obesity and type 2 diabetes mellitus: The influence of acute hyperinsulinemia, very-low calorie diet and PPAR- $\alpha$ agonist treatment. Physiol Res 60: 627-636.

Muise ES, Azzolina B, Kuo DW, El-Sherbeini M, Tan Y, Yuan X, $\mathrm{Mu}$ J, Thompson JR, Berger JP, Wong KK. 2008. Adipose fibroblast growth factor 21 is up-regulated by peroxisome proliferator-activated receptor $\gamma$ and altered metabolic states. Mol Pharmacol 74: 403-412.

Nagano M, Kuroki S, Mizuta A, Furukawa M, Noshiro M, Chijiiwa K, Tanaka M. 2004. Regulation of bile acid synthesis under reconstructed enterohepatic circulation in rats. Steroids 69: 701-709.

Nagashima K, Lopez C, Donovan D, Ngai C, Fontanez N, Bensadoun A, Fruchart-Najib J, Holleran S, Cohn JS, Ramakrishnan R, et al. 2005. Effects of the PPAR $y$ agonist pioglitazone on lipoprotein metabolism in patients with type 2 diabetes mellitus. J Clin Invest 115: 1323-1332.

Nicholes K, Guillet S, Tomlinson E, Hillan K, Wright B, Frantz GD, Pham TA, Dillard-Telm L, Tsai SP, Stephan JP, et al. 2002. A mouse model of hepatocellular carcinoma: Ectopic expression of fibroblast growth factor 19 in skeletal muscle of transgenic mice. Am J Pathol 160: 2295-2307.

Nishimura T, Utsunomiya Y, Hoshikawa M, Ohuchi H, Itoh N. 1999. Structure and expression of a novel human FGF, FGF-19, expressed in the fetal brain. Biochim Biophys Acta 1444: $148-151$.

Nishimura T, Nakatake Y, Konishi M, Itoh N. 2000. Identification of a novel FGF, FGF-21, preferentially expressed in the liver. Biochim Biophys Acta 1492: 203-206.

Oakes ND, Thalen PG, Jacinto SM, Ljung B. 2001. Thiazolidinediones increase plasma-adipose tissue FFA exchange capacity and enhance insulin-mediated control of systemic FFA availability. Diabetes 50: 1158-1165.

Ogawa Y, Kurosu H, Yamamoto M, Nandi A, Rosenblatt KP, Goetz R, Eliseenkova AV, Mohammadi M, Kuro-o M. 2007. $\beta$ Klotho is required for metabolic activity of fibroblast growth factor 21. Proc Natl Acad Sci 104: 7432-7437.

Oishi K, Sakamoto K, Konishi M, Murata Y, Itoh N, Sei H. 2010. FGF21 is dispensable for hypothermia induced by fasting in mice. Neuroendocrinol Lett 31: 198-202.

Oishi K, Konishi M, Murata Y, Itoh N. 2011. Time-imposed daily restricted feeding induces rhythmic expression of Fgf21 in white adipose tissue of mice. Biochem Biophys Res Commun 412: 396-400.

Pai R, Dunlap D, Qing J, Mohtashemi I, Hotzel K, French DM. 2008. Inhibition of fibroblast growth factor 19 reduces tumor growth by modulating $\beta$-catenin signaling. Cancer Res 68: 5086-5095.

Pandak WM, Li YC, Chiang JY, Studer EJ, Gurley EC, Heuman DM, Vlahcevic ZR, Hylemon PB. 1991. Regulation of cho- 
lesterol $7 \alpha$-hydroxylase mRNA and transcriptional activity by taurocholate and cholesterol in the chronic biliary diverted rat. I Biol Chem 266: 3416-3421.

Potthoff MJ, Inagaki T, Satapati S, Ding X, He T, Goetz R, Mohammadi M, Finck BN, Mangelsdorf DJ, Kliewer SA, et al. 2009. FGF21 induces PGC- $1 \alpha$ and regulates carbohydrate and fatty acid metabolism during the adaptive starvation response. Proc Natl Acad Sci 106: 10853-10858.

Potthoff MJ, Boney-Montoya J, Choi M, He T, Sunny NE, Satapati S, Suino-Powell K, Xu HE, Gerard RD, Finck BN, et al. 2011. FGF15/19 regulates hepatic glucose metabolism by inhibiting the CREB-PGC-1 $\alpha$ pathway. Cell Metab 13: 729-738.

Reiche M, Bachmann A, Lossner U, Bluher M, Stumvoll M, Fasshauer M. 2010. Fibroblast growth factor 19 serum levels: Relation to renal function and metabolic parameters. Horm Metab Res 42: 178-181.

Reshef L, Olswang Y, Cassuto H, Blum B, Croniger CM, Kalhan SC, Tilghman SM, Hanson RW. 2003. Glyceroneogenesis and the triglyceride/fatty acid cycle. I Biol Chem 278: 3041330416.

Russell DW. 2003. The enzymes, regulation, and genetics of bile acid synthesis. Annu Rev Biochem 72: 137-174.

Russell DW, Setchell KD. 1992. Bile acid biosynthesis. Biochemistry 31: 4737-4749.

Sarruf DA, Thaler JP, Morton GJ, German J, Fischer JD, Ogimoto K, Schwartz MW. 2010. Fibroblast growth factor 21 action in the brain increases energy expenditure and insulin sensitivity in obese rats. Diabetes 59: 1817-1824.

Sawey ET, Chanrion M, Cai C, Wu G, Zhang J, Zender L, Zhao A, Busuttil RW, Yee H, Stein L, et al. 2011. Identification of a therapeutic strategy targeting amplified FGF19 in liver cancer by oncogenomic screening. Cancer Cell 19: 347-358.

Schaap FG, van der Gaag NA, Gouma DJ, Jansen PL. 2009. High expression of the bile salt-homeostatic hormone fibroblast growth factor 19 in the liver of patients with extrahepatic cholestasis. Hepatology 49: 1228-1235.

Shimada T, Mizutani S, Muto T, Yoneya T, Hino R, Takeda S, Takeuchi Y, Fujita T, Fukumoto S, Yamashita T. 2001. Cloning and characterization of FGF2 3 as a causative factor of tumor-induced osteomalacia. Proc Natl Acad Sci 98: 6500-6505.

Squire TL, Lowe ME, Bauer VW, Andrews MT. 2003. Pancreatic triacylglycerol lipase in a hibernating mammal. II. Coldadapted function and differential expression. Physiol Genomics 16: 131-140.

Stejskal D, Karpisek M, Hanulova Z, Stejskal P. 2008. Fibroblast growth factor-19: Development, analytical characterization and clinical evaluation of a new ELISA test. Scand J Clin Lab Invest 68: 501-507.

Suzuki M, Uehara Y, Motomura-Matsuzaka K, Oki J, Koyama Y, Kimura M, Asada M, Komi-Kuramochi A, Oka S, Imamura T. 2008. $\beta$ Klotho is required for fibroblast growth factor (FGF) 21 signaling through FGF receptor (FGFR) 1c and FGFR3c. Mol Endocrinol 22: 1006-1014.

Swoap SJ, Weinshenker D. 2008. Norepinephrine controls both torpor initiation and emergence via distinct mechanisms in the mouse. PLOS ONE 3: e4038. doi: 10.1371/journal.pone. 0004038.

Thissen JP, Ketelslegers JM, Underwood LE. 1994. Nutritional regulation of the insulin-like growth factors. Endocr Rev 15: 80-101.

Tomiyama K, Maeda R, Urakawa I, Yamazaki Y, Tanaka T, Ito S, Nabeshima Y, Tomita T, Odori S, Hosoda K, et al. 2010. Relevant use of Klotho in FGF19 subfamily signaling system in vivo. Proc Natl Acad Sci 107: 1666-1671.
Tomlinson E, Fu L, John L, Hultgren B, Huang X, Renz M, Stephan JP, Tsai SP, Powell-Braxton L, French D, et al. 2002. Transgenic mice expressing human fibroblast growth factor19 display increased metabolic rate and decreased adiposity. Endocrinology 143: 1741-1747.

Uebanso T, Taketani Y, Yamamoto H, Amo K, Ominami H, Arai H, Takei Y, Masuda M, Tanimura A, Harada N, et al. 2011. Paradoxical regulation of human FGF21 by both fasting and feeding signals: Is FGF21 a nutritional adaptation factor? PLOS ONE 6: e22976. doi: 10.1371/journal.pone.0022976.

Urakawa I, Yamazaki Y, Shimada T, Iijima K, Hasegawa H, Okawa K, Fujita T, Fukumoto S, Yamashita T. 2006. Klotho converts canonical FGF receptor into a specific receptor for FGF23. Nature 444: 770-774.

Walters JR, Tasleem AM, Omer OS, Brydon WG, Dew T, le Roux CW. 2009. A new mechanism for bile acid diarrhea: Defective feedback inhibition of bile acid biosynthesis. Clin Gastroenterol Hepatol 7: 1189-1194.

Wang L, Lee YK, Bundman D, Han Y, Thevananther S, Kim CS, Chua SS, Wei P, Heyman RA, Karin M, et al. 2002. Redundant pathways for negative feedback regulation of bile acid production. Dev Cell 2: 721-731.

Wang H, Qiang L, Farmer SR. 2008. Identification of a domain within peroxisome proliferator-activated receptor $\gamma$ regulating expression of a group of genes containing fibroblast growth factor 21 that are selectively repressed by SIRT1 in adipocytes. Mol Cell Biol 28: 188-200.

Wei W, Dutchak PA, Wang X, Ding X, Wang X, Bookout AL, Goetz R, Mohammadi M, Gerard RD, Dechow PC, et al. 2012. Fibroblast growth factor 21 promotes bone loss by potentiating the effects of PPAR- $\gamma$. Proc Natl Acad Sci doi: 10.1073/pnas.1200797109.

Wente W, Efanov AM, Brenner M, Kharitonenkov A, Koster A, Sandusky GE, Sewing S, Treinies I, Zitzer H, Gromada J. 2006. Fibroblast growth factor- 21 improves pancreatic $\beta$-cell function and survival by activation of extracellular signalregulated kinase $1 / 2$ and Akt signaling pathways. Diabetes 55: 2470-2478.

White KE, Evans WE, O'Riordon JLH, Speer MC, Econs MJ, Lorenz-Depiereux B, Grabowski M, Meitinger T, Strom TM. 2000. Autosomal dominant hypophosphataemic rickets is associated with mutations in FGF23. Nat Genet 26: 345-348.

Wong BS, Camilleri M, Carlson PJ, Guicciardi ME, Burton D, McKinzie S, Rao AS, Zinsmeister AR, Gores GJ. 2011. A Klotho $\beta$ variant mediates protein stability and associates with colon transit in irritable bowel syndrome with diarrhea. Gastroenterology 140: 1934-1942.

Wu X, Ge H, Gupte J, Weiszmann J, Shimamoto G, Stevens J, Hawkins N, Lemon B, Shen W, Xu J, et al. 2007. Co-receptor requirements for fibroblast growth factor-19 signaling. I Biol Chem 282: 29069-29072.

Wu X, Ge H, Lemon B, Weiszmann J, Gupte J, Hawkins N, Li X, Tang J, Lindberg R, Li Y. 2009. Selective activation of FGFR4 by an FGF19 variant does not improve glucose metabolism in ob/ob mice. Proc Natl Acad Sci 106: 14379-14384.

Wu X, Ge H, Lemon B, Vonderfecht S, Baribault H, Weiszmann J, Gupte J, Gardner J, Lindberg R, Wang Z, et al. 2010a. Separating mitogenic and metabolic activities of fibroblast growth factor 19 (FGF19). Proc Natl Acad Sci 107: 1415814163.

Wu X, Ge H, Lemon B, Vonderfecht S, Weiszmann J, Hecht R, Gupte J, Hager T, Wang Z, Lindberg R, et al. 2010b. FGF19induced hepatocyte proliferation is mediated through FGFR4 activation. I Biol Chem 285: 5165-5170.

Wu AL, Coulter S, Liddle C, Wong A, Eastham-Anderson J, French DM, Peterson AS, Sonoda J. 2011. FGF19 regulates 
Potthoff et al.

cell proliferation, glucose and bile acid metabolism via FGFR4-dependent and independent pathways. PLOS ONE 6: e17868. doi: 10.1371/journal.pone.0017868.

Xie MH, Holcomb I, Deuel B, Dowd P, Huang A, Vagts A, Foster J, Liang J, Brush J, Gu Q, et al. 1999. FGF-19, a novel fibroblast growth factor with unique specificity for FGFR4. Cytokine 11: 729-735.

Xu J, Lloyd DJ, Hale C, Stanislaus S, Chen M, Sivits G, Vonderfecht S, Hecht R, Li YS, Lindberg RA, et al. 2009a. Fibroblast growth factor 21 reverses hepatic steatosis, increases energy expenditure, and improves insulin sensitivity in diet-induced obese mice. Diabetes 58: 250-259.

Xu J, Stanislaus S, Chinookoswong N, Lau YY, Hager T, Patel J, Ge H, Weiszmann J, Lu SC, Graham M, et al. 2009b. Acute glucose-lowering and insulin-sensitizing action of FGF21 in insulin resistant mouse models-association with liver and adipose tissue effects. Am I Physiol Endocrinol Metab 297: E1105-E1114. doi: 10.1152/ajpendo.00348.2009.

Yang F, Huang X, Yi T, Yen Y, Moore DD, Huang W. 2007. Spontaneous development of liver tumors in the absence of the bile acid receptor farnesoid X receptor. Cancer Res 67: 863-867.

Yilmaz Y, Eren F, Yonal O, Kurt R, Aktas B, Celikel CA, Ozdogan O, Imeryuz N, Kalayci C, Avsar E. 2010. Increased serum FGF21 levels in patients with nonalcoholic fatty liver disease. Eur J Clin Invest 40: 887-892.

Yu C, Wang F, Kan M, Jin C, Jones RB, Weinstein M, Deng CX, McKeehan WL. 2000. Elevated cholesterol metabolism and bile acid synthesis in mice lacking membrane tyrosine kinase receptor FGFR4. I Biol Chem 275: 15482-15489.

Yu C, Wang F, Jin C, Huang X, McKeehan WL. 2005. Independent repression of bile acid synthesis and activation of c-Jun $\mathrm{N}$-terminal kinase (JNK) by activated hepatocyte fibroblast growth factor receptor 4 (FGFR4) and bile acids. I Biol Chem 280: 17707-17714.

Zhang J, Kaasik K, Blackburn MR, Lee CC. 2006. Constant darkness is a circadian metabolic signal in mammals. Nature 439: 340-343.

Zhang X, Yeung DC, Karpisek M, Stejskal D, Zhou ZG, Liu F, Wong RL, Chow WS, Tso AW, Lam KS, et al. 2008. Serum FGF21 levels are increased in obesity and are independently associated with the metabolic syndrome in humans. Diabetes 57: 1246-1253.

Zhang Y, Xu P, Park K, Choi Y, Moore DD, Wang L. 2008. Orphan receptor small heterodimer partner suppresses tumorigenesis by modulating cyclin D1 expression and cellular proliferation. Hepatology 48: 289-298.

Zweers SJ, Booij KA, Komuta M, Roskams T, Gouma DI, Jansen PL, Schaap FG. 2011. The human gallbladder secretes fibroblast growth factor 19 (FGF19) into bile: Towards defining the role of FGF19 in the enterobiliary tract. Hepatology doi: 10.1002/hep.24702. 


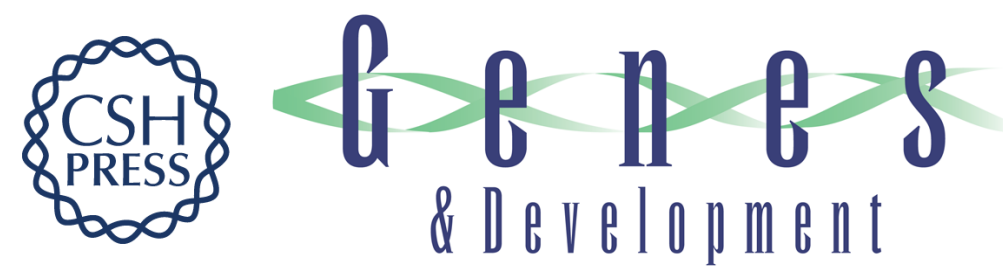

\section{Endocrine fibroblast growth factors $15 / 19$ and 21: from feast to famine}

Matthew J. Potthoff, Steven A. Kliewer and David J. Mangelsdorf

Genes Dev. 2012, 26: originally published online February 2, 2012

Access the most recent version at doi:10.1101/gad.184788.111

References This article cites 138 articles, 41 of which can be accessed free at:

http://genesdev.cshlp.org/content/26/4/312.full.html\#ref-list-1

License

Email Alerting Receive free email alerts when new articles cite this article - sign up in the box at the top Service right corner of the article or click here.

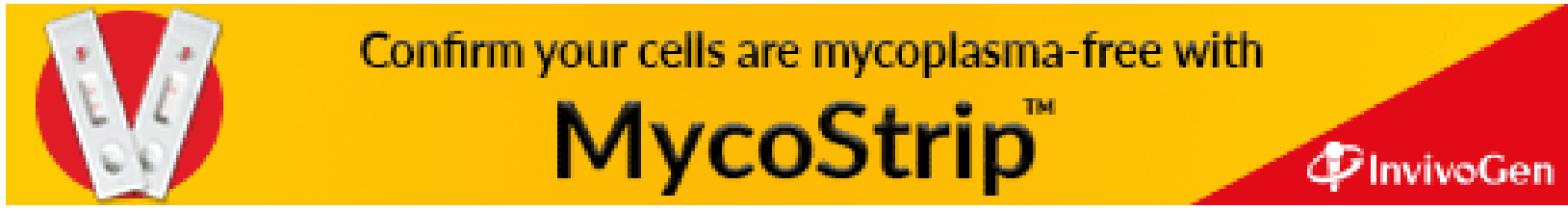

